\title{
NOTES AND CASE COMMENTS \\ A COMMENT ON MELSNESS V. MINISTER OF SOCIAL SERVICES AND COMMUNITY HEALTH
}

\author{
DAVID PHILLIP JONES*
}

The unanimous decision of the Court of Appeal of Alberta in Melsness v. Minister of Social Services and Community Health, ${ }^{1}$ recognizes a very narrow limitation on the applicability of the "duty to be fair". ${ }^{2}$ It is therefore important to examine the reasoning of the court in this case, and to determine just how broad is this exception to natural justice.

\section{FACTS AND ISSUE}

Mr. Melsness had been employed by the Government of Alberta since 1961. In 1970, he was designated Director of Child Welfare under the Child Welfare Act, ${ }^{3}$ which the Court held to be a "public office". ${ }^{4}$ In March 1981, he was unilaterally and without either forewarning or hearing removed from his office, relieved of those duties, and assigned to another position in the civil service. His application for an order in the nature of certiorari was successful before the Court of Queen's Bench on the grounds that he was entitled to a fair hearing before being dismissed from his office, even though the office (as opposed to his status as a civil servant) was held "at pleasure". Stevenson J., writing for the unanimous Court of Appeal, ${ }^{5}$ reversed the trial judge, and upheld the lawfulness of the Minister's dismissal of Mr. Melsness.

\section{THE COURT'S REASONING}

Because the Director's office was held at pleasure, the Minister could dismiss him arbitrarily - that is, for no reason, or for any reason; and such dismissal would not be an actionable wrong. Accordingly, Stevenson J. held that it would be pointless to require a hearing in such case, precisely because the Minister could even after a hearing dismiss Melsness from his office, without any obligation to give reasons therefor.

In reaching this conclusion, Stevenson J. considered two conflicting lines of authority. On the one hand, as Lord Reid said in Ridge v. Baldwin: ${ }^{6}$

Then there are many cases where a man holds an office at pleasure. Apart from judges and other whose tenure of office is governed by statute, all servants and officers of the Crown hold office at pleasure, and this has been held even to apply to a colonial judge ..... It has always been held, I

w think rightly, that such an officer has no right to be heard before he is dismissed, and the reason is clear. As the person having the power of dismissal need not have anything against the officer, he need not give any reason ..... I fully accept that where an office is simply held at pleasure the

* Of the Faculty of Law at The University of Alberta. I am grateful to my colleague, F.A. Laux, for his comments on an earlier version.

1. [1982] 3 W.W.R. 206.

2. See D.P. Jones, "Administrative Fairness in Alberta" (1980) 18 Alta. L. Rev. 351.

3. Now R.S.A. 1980, c. C-8.

4. Without defining what constitutes a "public office". See also McCarthy v. Bd. of Trustees of Calgary R.C. Sep. School District No. 1 [1979] 4 W.W.R. 725, 101 D.L.R. (3d) 48, 26 A.R. 1, 30 A.R. 232, (affirmed on appeal; unreported).

5. Comprised of McDermid, Belzil and Stevenson JJ.A.

6. [1964] A.C. 40 at 65.66 (H.L.) (emphasis added). 
person having power of dismissal cannot be bound to disclose his reasons. No doubt he would in many cases tell the officer and hear his explanation before deciding to dismiss him. But ifhe is not bound to disclose his reason and does not do so, then, if the court cannot require him to do so, it cannot determine whether it would be fair to hear the officer's case before taking action.

\section{On the other hand, Laskin C.J.C. said in Nicholson v. Haldimand-Norfolk} Regional Board of Police Commissioners: ${ }^{7}$

I would observe here that the old common law rule, deriving much of its force from Crown law, that a person engaged as an office holder at pleasure may be put out without reason or prior notice ought itself to be re-examined. It has an anachronistic flavour in the light of collective agreements, which are pervasive in both public and private employment, and which offer broad protection against arbitrary dismissal in the case of employees who cannot claim the status of office holders. As S.A. de Smith has pointed out in his book Judicial Review of Administrative Action, 3rd ed. (1973), at p. 200, "public policy does not dictate that tenure of an office held at pleasure should be terminable without allowing its occupant any right to make prior representa. tions on his own behalf; indeed, the unreviewability of the substantive grounds for removal indicates that procedural protection may be all the more necessary". The judgment of the House of Lords in Malloch v. Aberdeen Corporation, [1971] 2 All E.R. 1278 is a useful reference in this connection. In that case the statutory provision for appointment of teachers at pleasure was qualified by a restriction against dismissal without due notice and due deliberation by the school board. Observations were there made about the holding of an office at pleasure, and I refer particularly to what Lord Wilberforce said, at pp. 1295-6, where he commented as follows on Lord Reid's statement in Ridge v. Baldwin, supra, that an officer holding during pleasure has no right to be heard before being dismissed:

As a general principle, I respectfully agree; and I think it important not to weaken a principle which, for reasons of public policy, applies, at least as a starting point, to so wide a range of the public service. The difficulty arises when, as here, there are other incidents of the employ. ment laid down by statute, or regulations, or code of employment or agreement. The rigour of the principle is often, in modern practice, mitigated for it has come to be perceived that the very possibility of dismissal without reason being given - action which may vitally affect a man's career or his pension - makes it all the more important for him, in suitable circum. stances to be able to state his case and, if denied the right to do so, to be able to have his dismissal declared void. So, while the courts will necessarily respect the right, for good reasons of public policy, to dismiss without assigned reasons, this should not, in my opinion, prevent them from examining the framework and context of the employment to see whether elementary rights are conferred on him expressly or by necessary implication, and how far these extend. The present case is, in my opinion, just such a case where there are strong indications that a right to be heard, in appropriate circumstances, should not be denied.

Stevenson J. noted that both Lord Reid's and Chief Justice Laskin's comments were obiter dicta. ${ }^{8} \mathrm{He}$ also noted that Lord Wilberforce in Malloch did not deviate from Lord Reid's view of the law, but had to deal with a different circumstance: namely, an office held at pleasure but to which certain statutory restrictions of a procedural nature were placed on the unfettered power to dismiss arbitrarily. His Lordship also noted that Mr. Melsness could not be dismissed from the civil service (as opposed to being dismissed from his office as Director) without cause, or without a hearing.

\section{COMMENT}

Unfortunately, Stevenson J. does not appear to have considered the policy rationale underlying the principles of natural justice or the duty to be fair. This rationale is surely the belief that a man should not be "condemned" unheard, that better decisions in fact are made if the person affected by a proposed decision has an opportunity to be heard first. Such, anyway, is the basis for both de Smith's and Wade's criticisms of Lord

7. [1979] S.C.R. 311 at 322-324, 88 D.L.R. (3d) 671 at $679-680$ (emphasis added).

8. Quaere: whether it is strictly true that Chief Justice Laskin's comments were in fact obiter dicta. 
Reid's willingness to deprive the holder of an office at pleasure of the right to be heard. As Wade says: ${ }^{9}$

As already explained, natural justice does not itself require the giving of reasons for decisions, but nevertheless it does require a fair notice of the case to be met, and this requirement of notice is something quite different from a duty to give reasons for the decision taken. If the officer is subject to some accusation, justice requires that he should be allowed a fair opportunity to defend himself whatever the terms of his tenure.

Stevenson J. rejected this argument because ${ }^{10}$

$\ldots$. it assumes that there is a reason for dismissal and that the reason must be given in order that the case may be met.... It seems to me that it is this requirement which is at the root of Lord Reid's rejection of a right to a hearing when an office is held at pleasure. It was conceded in argument before us that the right to dismiss was a right to dismiss arbitrarily, without reason. The consequence of holding that procedural fairness applies in this particular case is to require the Minister to disclose his reasons, or if such be the case, to state that he is exercising his arbitrary right of dismissal.

This reasoning can be criticized. First, it implies that the duty to adopt a fair procedure is co-extensive with the obligation to give reasons. " Stevenson J. says that it would be pointless to require the Minister to give the Director notice of the proposed dismissal if the Minister does not in law need to have - let alone give - reasons for the dismissal. With respect, this confuses two issues.

On the one hand, to say that an office held at pleasure may be terminated without reasons really is to note that the discretion to terminate is completely unfettered. This is unlike the case where termination is for cause or other specified grounds only, because then the discretion to terminate is fettered by the requirement that such cause or grounds exist. ${ }^{12}$ But the duty to be fair, and the principles of natural justice generally, do not impose substantive fetters on a discretion, but rather constrain the method or procedure by which such a discretion may be exercised. Numerous examples can be cited where the courts have struck down the purported exercise of a discretion because the principles of natural justice or fairness have been breached, even though the statutory delegate undoubtedly had the substantive power to take the action in question - e.g., Cooper v. Wandsworth Board of Works; ${ }^{13}$ Nicholson. ${ }^{14}$ Even unfettered discretion is constrained by legal rules: for example, the unfettered discretion must be exercised in good faith, only considering relevant matters, and it must be exercised by the correct person. Similarly, it is not a contradiction to assert that the exercise of even an unfettered discretion must observe the rules of natural justice or procedural fairness. Accordingly, the right of the Minister to give - or to have - no reasons for dismissing the Director from his office held at pleasure, is really no answer to the employee's right to be told of the proposed dismissal in advance, and

9. H.W.R. Wade, Administrative Law (4th ed. 1977) 477 (emphasis added).

10. Supra n. 1 at 212 (emphasis added).

11. And this clearly is wrong. In general, there is no obligation on an administrative tribunal (or even a court!) to give reasons, although such an obligation may sometimes be imposed by the Legislature. See s. 7 of the Administrative Procedures Act, R.S.A. 1980 , c. A.2, for a very restricted example. On the other hand, the principles of natural justice and the duty to be fair apply to a very broad range of administrative actions.

12. And the lack of such cause or grounds deprives the employer of his power to terminate the employee without notice.

13. (1863) 14 C.B.N.S. 180.

14. Supran. 7. 
to make representations -with respect thereto. Nor does such a requirement of procedural fairness limit the right of the Minister to exercise his unfettered power to dismiss the Director without reasons.

Secondly, Stevenson J. appears to be too concerned with the possibility that the Minister in fact might have no reason - no cause - to terminate the Director, and therefore might be embarrassed by acting arbitrarily in dismissing the Director without a hearing. Frankly, why should the Courts protect the Minister's sensibilities? If the Minister wishes to act arbitrarily, and may in law do so (after a hearing!), let him; but let him be seen to act in that manner.

Thirdly, Stevenson J. unduly defers to the right of the Legislature to oust the applicability of the principles of natural justice, in this case by implication from the statement that all public offices are to be held at pleasure. Under our system of government, a sovereign legislature may indeed specifically oust the application of the principles of natural justice, but the ouster must be specific and unequivocal..$^{15}$ In light of the strong judicial pronouncements by Laskin C.J.C. and Lord Wilberforce in favour of applying natural justice to dismissal from offices held at pleasure, surely the mere statement in the Interpretation Act $^{16}$ that all public offices are held at pleasure is not so clear a statement of legislative intention as to justify by implication such a wholesale restriction on these fundamental principles of fair procedure.

Fourthly, one might scrutinize very carefully the rationale assigned by Stevenson J. to the rule in this province that all public offices are to be held at pleasure. His Lordship said: ${ }^{17}$

Determination that public offices are, in this province, to be held "at pleasure" represents a determination of the Legislature as reflected in the Interpretation Act. Some consideration must, in my view, be given to the "good reason of public policy" that lies behind the holding of an office at pleasure. I take it that those holding offices where important decisions of a policy nature must be made (as is the case of the director) must have at all times the confidence of the appointing authority, here a minister of the Crown. The importance of that confidence is well illustrated here by s. 5(1) which I have quoted. That confidence can be destroyed because of factors which in no way reflect upon the ability or integrity of the office-holder. I have in mind as an example incompatability, whether of person or policy. What we are asked to do here is to change or redefine the appointing authority's rights in terminating an appointment. The legislature has already seen fit to protect appointees of civil service status from loss of their employment. I do not think it is our function to alter a well-understood relationship which the legislature has seen fit to incorporate expressly into the law of this province.

Logically extended, this rationale gives Cabinet Ministers unbridled power to direct and control the actions of every civil servant, because they can terminate every office held at pleasure, even if the office is not created by the Cabinet, but rather by the Legislature itself. ${ }^{18}$ After all, it is the Legislature which exercise its sovereign power to delegate specific discretions, powers and duties to the holder of the particular office. Administrative Law is quite clear that such a statutory delegate shall himself exercise the powers granted to him by the Legislature, and shall not fetter his

15. And not the reverse: there is no requirement that the Legislative must specifically refer to the principles of natural justice to make them applicable to the exercise of a delegated power.

16. R.S.A. 1980 , c. I-7.

17. Supran. 1 at 213.

18. And the distinction between the Legislature and the Cabinet is important. 
discretion by either adopting a policy or being dictated to by another person (such as the Minister or the Cabinet). How is this fundamental rule of Administrative Law to be preserved in practice if - as Stevenson J. suggests - the holder of the office can be arbitrarily dismissed, without notice of an opportunity to be heard? Which civil servant will have the courage (let alone the opportunity) to insist upon exercising the powers which the Legislature (not the Executive: note the difference) has conferred upon him?

Finally, perhaps one could observe that the real difficulty in this case lies in the dichotomy between the law relating to the dismissal of ordinary employees and that relating to persons whose employment has a "statutory tinge", whether derived from the fact that their employment is specifically dealt with by legislation or their employer is a creature of statute. In general, private employees have no security of tenure, and can be dismissed with cause or with notice. At least, the courts will not generally grant an order of specific performance requiring an employer to continue employing a terminated employee, even if the termination amounts to a wrongful dismissal. The private employee's remedy lies in damages only, to the extent that the termination breaches the contract of employment. On the other hand, why should the mere fact that the employment has a "statutory tinge" to it bring into play all of the Administrative Law rules of procedure and all of the remedies for breaches thereof? Why should a governmental employee - who may well perform a function that is identical to that in the private sector - be in a better position? This question remains, even if one can justify the application of Administrative Law rules and remedies to very important governmental employees, particularly if they hold an "office". ${ }^{19}$ Nevertheless, the stark contrast in the law applicable to private and public employment is simply unrealistic in today's world. As Chief Justice Laskin noted in Nicholson, ${ }^{20}$ a very large proportion of private employment in fact is governed by collective agreements, which make great inroads into the employer's unfettered right to get rid of a particular employee (even if he has to pay damages for wrongful dismissal). Of course, legally, the collective agreements may merely be characterized as a contractual variation of the general law applicable to private employment, effectively permitting reinstatement to employment of an employee who has been wrongfully dismissed. Nevertheless, the fact remains that a large proportion of the private work force has security of tenure and the right to procedural safeguards at least as important as those imported by Administrative Law. Why, therefore, should the courts be astute to restrict the application of the principles of Administrative Law to governmental employees, in light of the very great de facto security of tenure granted to unionized employees?

19. Supra n. 4.

20. Supran.7. 